\title{
Calcifying Fibrous Tumor: A Case Report
}

\author{
Kalsifiye Fibröz Tümör: Olgu Sunumu
}

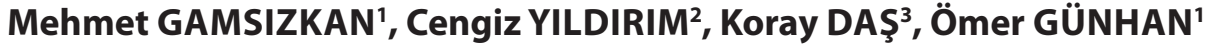 \\ 'Department of Pathology, Gülhane Military Medical Academy, Faculty of Medicine, ANKARA, TURKEY \\ ${ }^{2}$ Department of Orthopaedics and Traumatology, Tatvan Military Hospital, BITLIS, TURKEY \\ ${ }^{3}$ Department of General Surgery, Ankara Mevki Military Hospital, ANKARA, TURKEY
}

\begin{abstract}
Calcifying fibrous tumors are rarely seen and affect mostly children and young adults. A 21-year-old man presented with multiple palpable masses in the area from the right inguinal region to the anteromedial thigh. We performed a diagnostic excisional biopsy. Histopathologically, it was composed of fibroblasts, psammoma bodies, dystrophic calcifications and foci of mononuclear inflammatory cell infiltration in a collagenous dense stroma. We herein reported a case of calcifying fibrous tumor and discussed its clinical and morphological features with regard to the literature.
\end{abstract}

Key Words: Calcification, Fibrous tissue neoplasms, Pathology

\section{INTRODUCTION}

Calcifying fibrous tumor is a rare benign lesion. It was described for the first time in 1988 by Rosenthal et al. as a "Childhood fibrous tumor with psammoma bodies" in peripheral axial soft tissue (1) and, in 1993, Fetsch et al. re-named it as calcifying fibrous pseudotumor (2). At first, cases were diagnosed in subcutaneous and deep soft tissues (extremities, trunk, inguinal and scrotal regions, head and neck area). However, these tumors were gradually reported in other areas such as the visceral regions (pleura, mesentery, peritoneum), the oral cavity, and the adrenal gland $(3,4)$. Many cases in the literature have been described as "calcifying fibrous pseudotumor", however, we preferred to use the term "calcifying fibrous tumor" in accordance with World Health Organization (WHO) classification (3). We herein present a case of calcifying fibrous tumor in the right inguinal region extending to the anteromedial thigh and discuss its clinical and morphological features with regard to the literature.

\section{CASE REPORT}

A 21-year-old man presented with multiple masses which were localized from the right inguinal region to the

(Turk Patoloji Derg 2015, 31:141-144)

Received : 05.10.2011 Accepted : 21.11.2011

\section{Öz}

Kalsifiye fibröz tümör genellikle çocuk ve genç erişkinleri etkileyen nadir görülen benign fibröz bir lezyondur. Yirmi bir yaşında erkek hastada sağ inguinal bölgeden başlayarak uyluk anteromedial düzeye kadar uzanan, palpasyonda ele gelen çok sayıda kitleleri mevcuttu. Hastaya tanısal eksizyonel biyopsi uygulandı. Histopatolojik incelemede yoğun kollajenize bir stromada fibroblastlar, psammoma cisimleri, distrofik kalsifikasyonlar ve odaklar halinde mononükleer hücrelerden oluşan inflamatuar hücre infiltrasyonu dikkati çekti. Sunulan olguda, kalsifiye fibröz tümörün klinik ve morfolojik özelliklerine değinilmiş ve literatür eşliğinde tartışılmıştır.

Anahtar Sözcükler: Kalsifikasyon, Fibröz doku tümörleri, Patoloji

anteromedial thigh. He had gone to a hospital for treatment at the age of six due to a painless mass in the right inguinal region. The patient underwent an excisional biopsy for the mass; however, he was not informed about the diagnosis. Then, the masses recurred in the same region. There was no family history. Physical examination revealed palpable, nontender and semi-mobile multiple masses, from the right inguinal region to the anteromedial thigh. The largest one was about $3 \times 3 \mathrm{~cm}$ (Figure 1 A, B).

The patient's complete blood count and other routine biochemical values were within normal limits. Ultrasonographically, there were hypoechoic spherical-ovoid solid masses with regular margins including punctate echogenicity (Figure 2A). Magnetic resonance imaging (MRI) of the subcutaneous fatty tissue showed hypointense solid masses that were localized from the inguinal canal extending to the anteromedial thigh, on T1-T2-weighted images (Figure 2B).

We performed an excisional biopsy of one of the masses for histopathological diagnosis. Macroscopically, the lesion was a $3 \times 3 \times 2 \mathrm{~cm}$, gray-white, regularly contoured, unencapsulated solid mass. The cut surface was gritty in texture. Histo-

Correspondence: Mehmet GAMSIZKAN

Gülhane Askeri Tip Akademisi, Tip Fakültesi, Patoloji Anabilim Dalı, ANKARA, TURKEY

E-mail: drgamsiz@yahoo.com Phone: +90 3123045975 

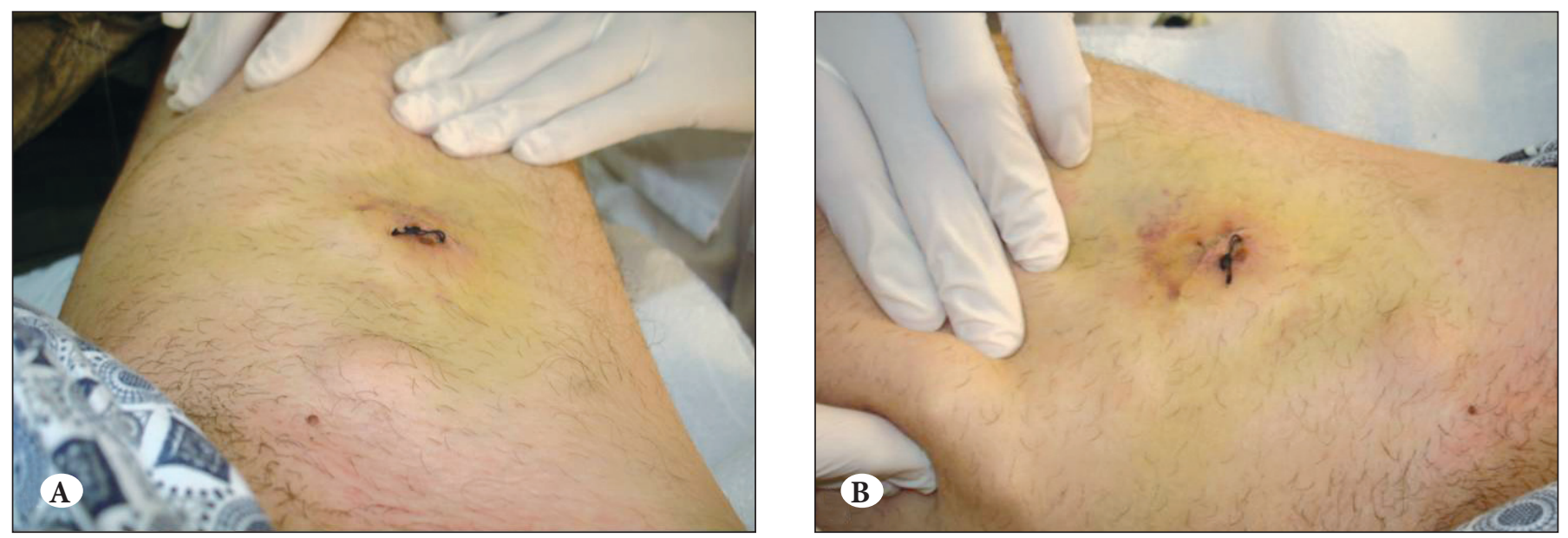

Figure 1A,B: Clinical photograph of the palpable masses on the right thigh.
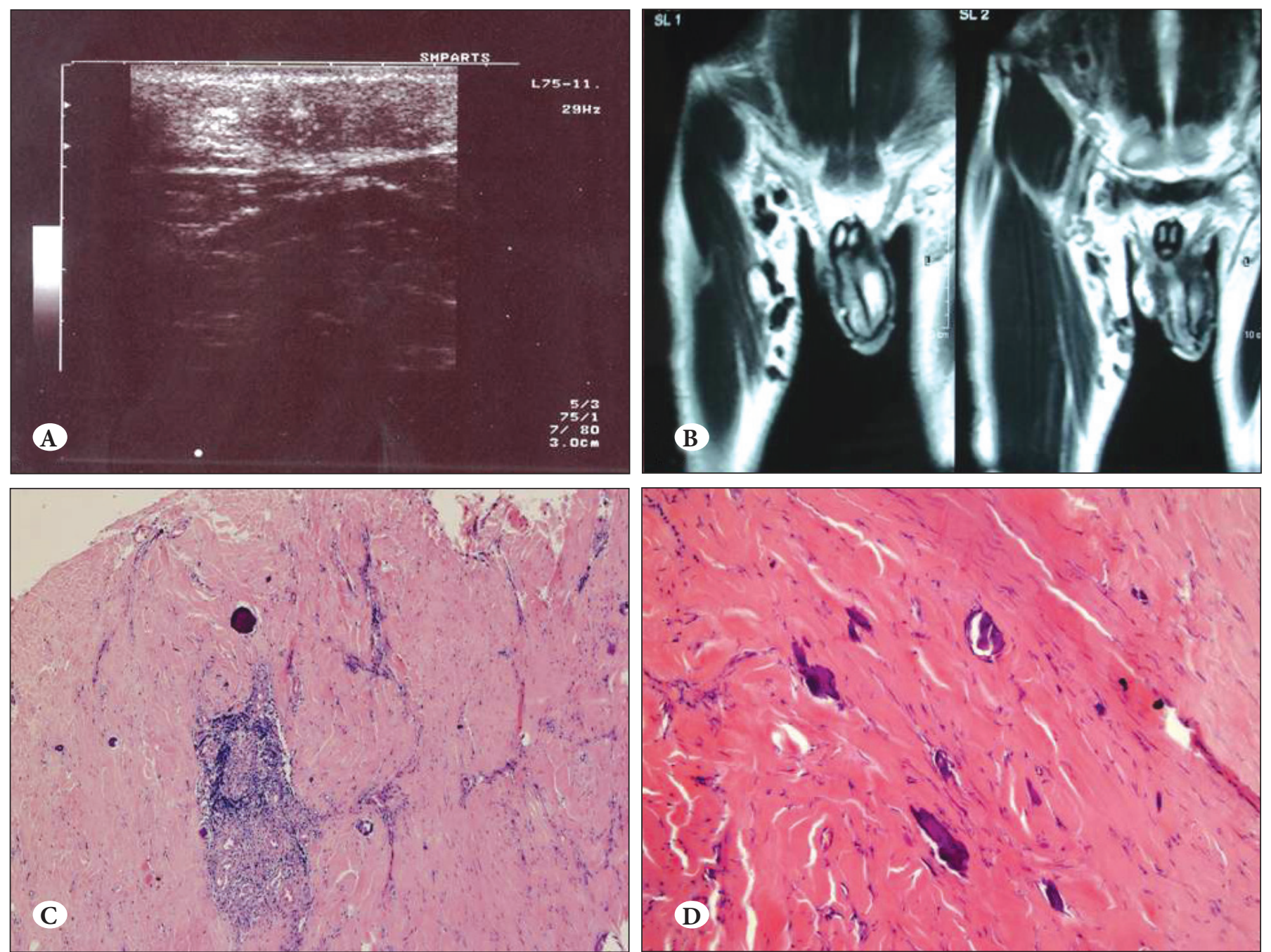

Figure 2: A) Ultrasonography demonstrating spherical-ovoid solid masses with regular margins including punctate echogenicity. B) MR images of the lesions. C) Lymphoid aggregates and psammomatous calcification (H\& E x50). D) Paucicellular and hyalinized fibrosclerotic tissue (H\&E x200). 


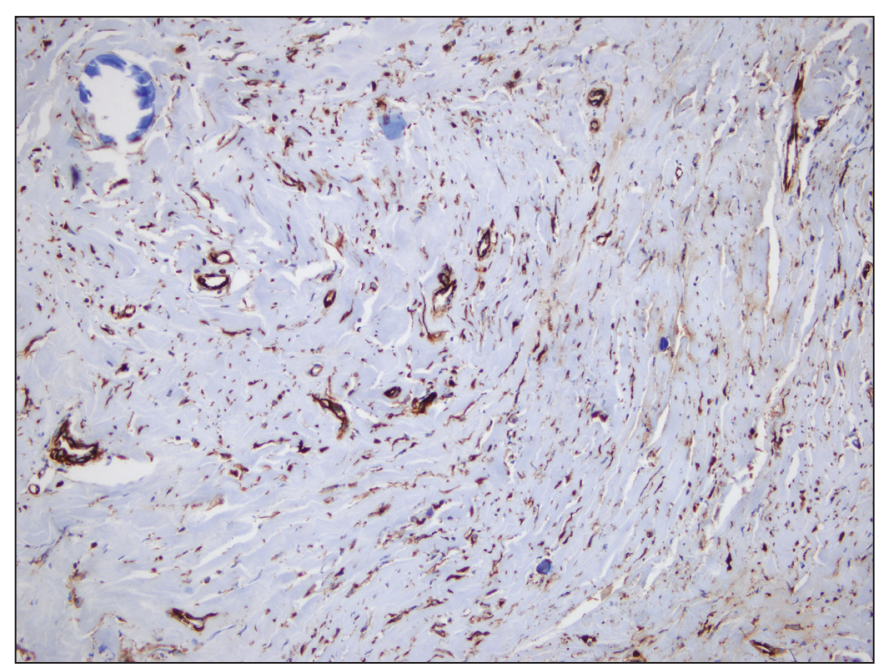

Figure 3: Vimentin expression in spindle cells (Vimentin x200).

pathologically, the tumor consisted of well circumscribed, unencapsulated, paucicellular, hyalinized fibrosclerotic tissue. There was neither cellular atypia nor mitotic figure in the fibroblasts. Lymphoid aggregates consisting of lymphocytes and plasma cells were also present. Psammomatous and dystrophic calcifications were scattered throughout the lesion. (Figure 2C, D). Immunohistochemically, spindle cells showed diffuse positivity for vimentin (Figure 3) and negativity for CD34, anaplastic lymphoma kinase (ALK), S-100, cytokeratin, actin, desmin and CD117. The lesion was diagnosed as calcifying fibrous tumor.

The patient was informed about his pathology and advised to undergo total surgical excision. Unfortunately, he left and never returned to complete the procedure and was therefore lost to clinical follow up.

\section{DISCUSSION}

Calcifying fibrous tumor (CFT) is a rarely seen entity that usually occurs in children and young adults, with a slight increase in risk in women. Clinically, it appears as a slow growing, nontender mass. Visceral symptoms may occur depending on the localization of the lesions. Radiographically, it is non-calcified and well circumscribed. Punctate, thick or band-like calcifications can be seen on Computed Tomography (CT). On MRI, the tumor may be similar to fibromatoses (3). Their etiopathogenesis has not been fully clarified yet. However, in the literature, there are cases that may be related to trauma and Castleman's disease (4-8). CFT is a benign lesion and metastasis has not been reported. Nascimento et al have observed local recurrences in 3 of 10 patients in his study (9). In our case there was no history of trauma, and the patient was otherwise healthy.
Macroscopically, CFT is well circumscribed and unencapsulated. Its diameter ranges from 1 to $15 \mathrm{~cm}$. In some cases the tumor may have indistinct boundaries; hence infiltration may be indistinguishable from the surrounding tissues. On sectioning, the tumor reveals a solid, grey-whitish and gritty texture.

Histopathologically, it is characterized by abundant hyalinized collagen tissue with lymphoplasmacytic mononuclear inflammatory cell infiltrate and dystrophic - psammomatous calcifications. Lymphoid aggregates can be found in some cases. Although immunohistochemical analysis is not necessary for diagnosis (4), fibroblasts do express vimentin and factor XIIIa and CD34 immunoexpression can be seen on rare occasions $(10,11)$. Ultrastructural studies show that calcifications occur as a result of cytoplasmic degeneration in the fibroblasts $(6,9)$.

The histopathological features of CFTs are generally easily recognizable from other reactive or benign neoplastic lesions. Inflammatory myofibroblastic tumor (IMT), reactive nodular fibrous pseudotumor (RNFP), nodular fasciitis, desmoid fibromatosis, fibroma of tendon sheath and calcifying aponeurotic fibroma might be considered in the differential diagnosis (12). IMT is composed of spindled myofibroblasts, fibroblasts, and inflammatory cells. It is more cellular and shows less hyalinization than CFT. In addition, a polymorphic inflammatory cell infiltration and occasional stromal calcification can be seen in IMT. Actin and ALK immunoexpression is positive in IMT $(9,14)$. In fact, some authors consider CFT to be a late sclerosing stage of IMT (4). In reactive nodular fibrous pseudotumor (RNFP), actin, desmin and CD117 immunoexpression is positive and CD34 is negative in addition to the characteristic histopathological features of CFT. Desmoid fibromatosis is poorly circumscribed with infiltration of the surrounding structures and more cellular than CFT. Nodular fasciitis is composed of plump myofibroblastic cells in a myxoid stroma without calcification. Fibromas of the tendon sheath generally occur in distal extremities such as the thumb and the fingers. It is composed of paucicellular spindled fibroblasts in a collagenous stroma and slit-like vascular channels. Calcifying aponeurotic fibroma is usually seen on the palms and soles of children. Its boundaries are more irregular than CFT. Band-like calcification, chondroid metaplasia and multinuclear giant cells can also be seen (3, 12).

There are few studies regarding cytogenetic abnormalities in calcifying fibrous tumors. By using fluorescent in situ hybridization, Hoffmann et al attempted to detect trisomy 7 and trisomy 8 which has been reported in other benign 
fibrous tumors. Due to the low signal intensity, they were not able to complete the study. (13). In another study, Fukunaga et al found that CFT had a diploid DNA content by flow cytometry (14). Whether CFT is a true neoplasm or a reactive process still remains unknown (13-15). Future molecular studies can be helpful for detecting the biologic behavior of CFT.

As a result, CFT is a rare benign lesion and conservative excision is sufficient to cure the patient. However, local recurrence can be seen in some cases. Thus clinical followup is important.

\section{THANKS}

The authors thank Armağan Günal for immunohistochemical evaluation.

\section{REFERENCES}

1. Rosenthal NS, Abdul-Karim FW. Childhood fibrous tumor with psammoma bodies. Clinicopathologic features in two cases. Arch Pathol Lab Med. 1988;112:798-800.

2. Fetsch JF, Montgomery EA, Meis JM. Calcifying fibrous pseudotumor. Am J Surg Pathol. 1993;17:502-8.

3. Montgomery E: Calcifying fibrous tumor. Fletcher CDM, Unni KK, Mertens F, editors. World Health Organization Classification of Tumours, pathology and genetics of tumours of soft tissue and bone. Lyon:IARC Press; 2002. 77-8.

4. Bell DM, Dekmezian RH, Husain SA, Luna MA. Oral calcifying fibrous pseudotumor: Case analysis and review. Head Neck Pathol. 2008;2:343-7.
5. Azam M, Husen YA, Pervez S. Calcifying fibrous pseudotumor in association with hyaline vascular type Castleman's disease. Indian J Pathol Microbiol. 2009;52:527-9.

6. Zamecnik M, Dorociak F, Vesely L. Calcifying fibrous pseudotumor after trauma. Pathol Int. 1997;47:812

7. Pomplun S, Goldstraw P, Davies SE, Burke MM, Nicholson AG. Calcifying fibrous pseudotumour arising within an inflammatory pseudotumour: Evidence of progression from one lesion to the other? Histopathology. 2000;37:380-2.

8. Hill KA, Gonzalez-Crussi F, Chou PM. Calcifying fibrous pseudotumor versus inflammator my ofibroblastic tumor: A histological and immunohistochemical comparison. Mod Pathol. 2001;14:784-90.

9. Nascimento AF, Ruiz R, Hornick JL, Fletcher CD. Calcifying fibrous 'pseudotumor': Clinicopathologic study of 15 cases and analysis of its relationship to inflammatory myofibroblastic tumor. Int J Surg Pathol. 2002;10:189-96.

10. Weynand B, Draguet AP, Bernard P, Marbaix E, Galant C. Calcifying fibrous pseudotumour: First case report in the peritoneum with immunostaining for CD34. Histopathology. 1999;34:86-7.

11. Maeda T, Hirose T, Furuya K, Kameoka K. Calcifying fibrous pseudotumor: An ultrastructural study. Ultrastruct Pathol. 1999; 23:189-92.

12. Enzinger and Weiss's Soft Tissue Tumors. 5th ed. Weiss SW, Goldblum JR, editors. Mosby Elsevier; 2008. 294-7.

13. Hoffmann H, Beaver ME, Maillard AAJ. Calcifying fibrous pseudotumor of the neck. Arch Pathol Lab Med. 2000;124:435-7.

14. Fukunaga M, Kikuchi Y, Endo Y, Ushigome S. Calcifying fibrous pseudotumor. Pathol Int. 1997;47:60-3.

15. Jiang K, Nie J, Wang J, Li J. Multiple calcifying fibrous pseudotumor of the bilateral pleura. Jpn J Clin Oncol. 2011;41:130-3. 